\title{
EDUKASI HIDUP SEHAT DAN BAHAGIA DENGAN ASUPAN GIZI YANG TEPAT PADA PEREMPUAN MENOPAUSE .
}

\author{
Syiddatul Budury \\ Universitas Nahdlatul Ulama Surabaya. \\ syiddatbr@unusa.ac.id \\ Andikawati Fitriasari \\ Universitas Nahdlatul Ulama Surabaya. \\ Andikawati_f@unusa.ac.id \\ Khamida \\ Universitas Nahdlatul Ulama Surabaya. \\ khamida@unusa.ac.id
}

\begin{abstract}
Abstrak
Pada fase menopause, menurunnya hormon estrogen dan progesteron dapat menimbulkan berbagai gejala psikologis berupa rasa takut menjadi tua, tidak menarik, sulit tidur, mudah marah, sangat emosional, merasa tertekan dan sedih tanpa diketahui sebabnya, rasa takut kehilangan suami. Kondisi ini kalau dibiarkan akan mampu membuat lansia mengalami kecemasan dan depresi yang akan berpengaruh terhadapa penurunan kualitas hidup. Tujuan pengabdian masyarakat ini adalah memberikan pemahaman tentang asupan gizi yang sesuai untuk fase menopause sehingga wanita yang menopause bisa hidup lebih sehat dan bahagia. Kegiatan ini diikuti oleh lansia yang tergabung di komunitas Griyo Lansia Abiyoso di Desa Kepuh Kiriman, Waru Sidoarja. Edukasi dilakukan dengan penyuluhan dan dibantu dengan booklet. Hasil penyuluhan menunjukkan bahwa lansia menjadi lebih mengetahui dan paham mengenai jenis makanan yang sehat dan baik untuk mereka konsumsi yaitu makanan yang mengandung fitoestrogen
\end{abstract}

Kata Kunci: Lansia, Gizi, Menopause.

\begin{abstract}
Estrogen and progesterone decreases during menopause phase. It caused psychological problems such afraid of getting old, unattractive, sleep disorder, easily getting upset, feeling pressured without knowing why, afraid of not being loved by her spouse. If it happens it will make an elderly getting anxiety disorder and depression that will affect to their quality of life. This community service aims to give education and consultation about healthy food during menopause to make an elderly which is in menopause living healthier and happier. This service was followed by elderly women who join Griyo Lansia community in Kepuh Kiriman Village, Waru Sidorajo. The methode was giving health education supported by booklet. And the result showed that elderly people having a good knowledge and knowing what kind of healthy food they will consume especially food that make estrogen relcintains phytoestrogen.
\end{abstract}

Keywords : Elderly, nutrition, menopause. 


\section{PENDAHULUAN}

Menopause merupakan masa penghentian menstruasi secara permanen yang terjadi karena hilangnya aktivitas folikel ovarium (Agaba et al., 2017) fase ini biasanya terjadi pada perempuan dengan rentang usia 48 sampai 55 tahun (Ashrafi M, 2016). Masa ini menjadi hal yang kompleks bagi seorang perempuan karena berkaitan dengan keadaan fisik dan kejiwaannya. Selain mengalami stress fisik perempuan menopause juga mengalami stress psikologi yang mempengaruhi keadaan emosi (Baziad, 2008)

Perempuan menopause akan menunjukkan tanda salah satunya adalah mudah marah, sulit tidur, merasa panas dalam tubuhnya (Roxby, 2019) kondisi ini memungkinkan lansia mengalami masalah kejiwaan seperti kecemasan dan depresi, selain itu lansia juga rentan mengalami osteoporosis dan tekanan darah tinggi. Maka dari itu lansia perlu mengkonsumsi makanan yang memiliki nutrisi yang cukup untuk meminimalisir keluhan fisik dan psikologis terutama makanan yang mengandung fitoestrogen.
Fitoestrogen adalah biji-bijian, kacangkacangan, sayuran dan buah-buahan yang memiliki sifat dan khasiat menyerupai hormon estrogen ( Biben, 2017). Salah satu contoh dari makanan yang mengandung fitoestrogen adalah susu kedelai, hasil penelitian menunjukkan bahwa mengkonsumsi susu kedelai mampu mengurangi kecemasan dan depresi pada lansia yang mengalami menopause (Fattah, 2017) selain mengurangi depresi dan kecemasan fitoestrogen juga bisa mengurangi sensasi terbakar (hot flush) yang dirasakan wanita menopause, meningkatkan densitas tulang dan meningkatkan fungsi kognitif. (Ariyanti, 2016)

Edukasi dan pengenalan makanan yang mengandung fitoestrogen dan makanan sehat lainnya pada wanita yang menopause, diharapkan mampu memperbaiki kualitas hidup lansia. Lansia menjadi lebih mengetahui dan peduli akan jenis makanan sehat yang akan mereka konsumsi.

\section{GAMBARAN MASYARAKAT SASARAN} UMUM

Komunitas Griyo Lansia Abiyoso di desa Kepuh Kiriman Waru Sidoarjo, kurang lebih ada 29 Lansia yang tergabung di komunitas tersebut, rentang usia mereka 
berada di usia 60 - 75 tahun. Salah satu kegiatan rutin mereka adalah senam pagi tiap hari Rabu dan Sabtu, waktu pengambilan data awal melalui wawancara pada 5 orang lansia didapatkan bahwa mereka belum pernah mendapat penyuluhan kesehatan tentang hal yang berkaitan dengan nutrisi saat menopause. Dari kondisi tersebut maka pelaksanaan pengabdian masyarakat tentang asupan gizi selama menopause perlu diberikan kepada lansia. Sehingga kegiatan ini diharapkan akan meningkatkan kualitas hidup lansia.

\section{METODE}

Metode pelaksanaan dalam program pengabdian kepada masyarakat yaitu dengan memberikan edukasi tentang asupan gizi pada lansia yang menopause. Peserta dari kegiatan ini adalah lansia yang tergabung di komunitas Griyo Lansia, desa Kepuh Kiriman Waru Sidoarjo.

Pendidikan kesehatan diberikan setelah kegiatan rutin senam pagi, lansia berkumpul di balai RW Kepuh Kiriman. Edukasi dilakukan dengan menggunakan LCD Proyektor dan leaflet. Keberadaan booklet tentang asupan dan jenis nutrisi yang diberikan pada lansia diharapkan dijadikan buku saku dalam panduan sehari-hari.

\section{HASIL DAN PEMBAHASAN}

Kegiatan pengabdian masyarakat dilakukan mulai dari Juli - Agustus 2019. Kegiatan awal yang dilakukan adalah survey lapangan, FGD dan dilanjutkan persiapan proposal pengabdian. Kegiatan dilaksanakan pada tanggal 3 Agustus 2019.

\section{Hasil FGD.}

Di Desa kepuh Kiriman sudah ada Posyandu lansia, tapi tidak pernah ada penyuluhan kesehatan. Dari hasil diskusi dengan anggota didapatkan mereka sudah berada berada dalam fase menopause namun mereka belum mengetahui segala hal yang tentang menopause, dan akhirnya mereka memutuskan ingin diberi penyuluhan tentang gizi yang baik selama fase menopause.

Pada hari Sabtu tanggal 3 Agustus 2019 dilaksanakan kegiatan penyuluhan, para wanita lansia sangat antusias dengan bertanya bermacam hal tentang asupan nutrisi yang dibutuhkan selama fase menopause. Salah satu pertanyaannya adalah : Makanan yang mengandung fitoestrogen itu apa benar bisa membantu proses pertumbuhan rambut dan kulit? Apakah dengan mengkonsumsi makanan yang sehat akan mampu mengurangi stres dan cemas? 
Hasil review dan wawancara setelah dilakukan edukasi menunjukkan peningkatan pengetahun, hal ini dibuktikan lansia mampu menjelaskan kembali jenis makanan yang mengandung fito estrogen, dan makanan yang harus dicegah agar memiliki status kesehatan yang baik.

Penelitian yang dilakukan di Chile menunjukkan hasil bahwa jenis makanan sehat yang dikonsumsi oleh lansia menjadi salah satu faktor yang dapat mempengaruhi tingkat kepuasan dan kebahagiaan hidup lansia (Lobos et al., 2016) hal ini sejalan dengan tujuan dari kegiatan pengabdian masyarakat ini, bahwa lansia akan mampu meningkatkan kualitas dan kebahagiaan hidup salah satunya dengan mengkonsumsi makanan yang sehat dan bergizi.

\section{Luaran yang Dicapai.}

Luaran yang dicapai dari kegiatan pengabdian masyarakat tentang "Edukasi Hidup Sehat Dan Bahagia Dengan Asupan Gizi Yang Tepat Pada Perempuan Menopause" di Desa kepuh Kiriman Waru Sidoarjo adalah sebagai berikut :

1. Peningkatan pengetahuan para perempuan menopause tentang asupan gizi yang tepat.
2. Adanya booklet tentang gizi yang dapat dijadikan acuan dalam mengkonsumsi makanan seharihari.

\section{KESIMPULAN}

Edukasi untuk meningkatkan pengetahuan perempuan menopuase tentang asupan asupan gizi yang tepat adalah satu metode agar lansia mampu meningkatkan kepedulian pada gizi dan nutrisi.

\section{REFERENSI}

Agaba, P. et al. (2017) 'Factors associated with early menopause among women in Nigeria.', Journal of virus eradication, 3(3), pp. 145-151. Available at: http://www.ncbi.nlm.nih.gov/pubm ed/28758022\%0Ahttp://www.pub medcentral.nih.gov/articlerender.fc gi?artid=PMC5518243.

Ashrafi M, K. (2016) 'Symptoms of natural menopause among Irania1n women who were living in Tehran', Iranian Journal of Reproductive Medicine, 8.

Baziad, A. (2008) Kontrasepsi Hormonal. Bina Pustaka.

Fattah, A. (2017) 'Effect of Phytoestrogen on Depression and Anxiety in Menopausal Women: A 
Systematic Review', Journal of Menopausal Medicine, 23(3), p. 160. doi:

10.6118/jmm.2017.23.3.160.

Hesti Ariyanti, E. A. (2016) 'Pengaruh

Fitoestrogen terhadap Gejala Menopause', Jurnal Kedokteran Universitas Lampung, 5(5).

Lobos, G. et al. (2016) 'With Health and Good Food, Great Life! Gender Differences and Happiness in Chilean Rural Older Adults', Social Indicators Research, 127(2), pp. 865-885. doi: 10.1007/s11205-015-0971-0.

Philippa Roxby (2019) Apa yang terjadi pada tubuh perempuan setelah menopause? Available at: https://www.bbc.com/indonesia/m ajalah-48428755.

Prof. Dr. dr. H A Biben, SpOG, K.-F. (2017) Fitoestrogen: Khasiat Terhadap Sistem Reproduksi, Non Reproduksi dan Keamanan Penggunaannya, Journal of Chemical Information and Modeling. doi: 10.1017/CBO9781107415324.004. 